
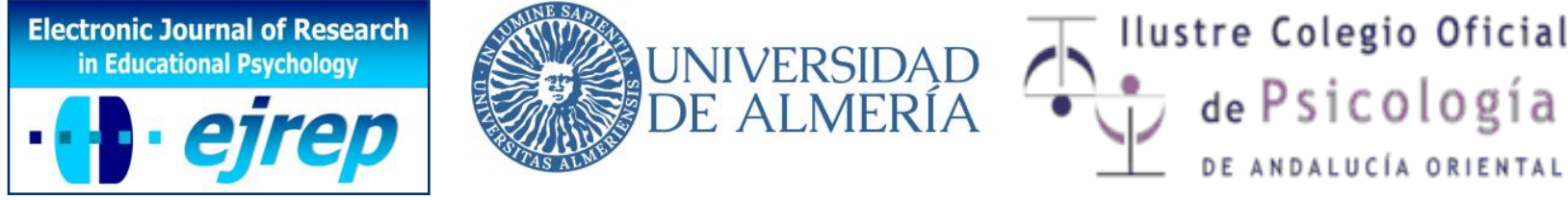

\title{
The Enhanced Career Decision-Making Self-Efficacy by Emotional Intelligence Depended on Proactive Personality
}

\section{Kusumasari K. H. Darmayanti ${ }^{1}$, Rose Mini Agoes Salim ${ }^{1}$}

${ }^{1}$ Faculty of Psychology, Universitas Indonesia, Jakarta

Indonesia

Correspondencia: Kusumasari Kartika Hima Darmayanti. Fakultas Psikologi, Universitas Indonesia, Jl. Lkr. Kampus Raya Jl. Mawar No.5 3 8, Pondok Cina, Beji, Depok, Jawa Barat 16424.

E-mail: kusumasarikhd@gmail.com

(C) Universidad de Almería and Ilustre Colegio Oficial de la Psicología de Andalucía Oriental (Spain) 


\section{Abstract}

Introduction. Adolescence is a transition period between childhood and adulthood during which a decision to embark on a career is made. Furthermore, emotional intelligence is linked to self-efficacy in career decision-making, and some adolescents possess a proactive personality trait that seemingly strengthens the relation between the two concepts.

Method. This study evaluated relations between emotional intelligence and career decisionmaking self-efficacy and considered whether such relations are moderated (strengthened or weakened) by proactive personality. A group sample $(N=840)$ from state senior high schools in Indonesia was surveyed.

Results. Career decision-making self-efficacy correlated with emotional intelligence. Additionally, proactive personality had a moderating effect on the relation between emotional intelligence and career decision-making self-efficacy.

Discussion and Conclusion. There is a significant positive relation exists between the two factors, and the hypothesis is accepted. The role of proactive personality suggests that career interventions should emphasize proactive personality aspects to increase the career decisionmaking self-efficacy of adolescents

Keywords: career decision-making self-efficacy; adolescent; emotional intelligence; proactive personality. 


\section{Resumen}

Introducción. La adolescencia es un período de transición entre la infancia y la edad adulta durante el cual se toma la decisión de emprender una carrera. Además, la inteligencia emocional está vinculada a la autoeficacia en la toma de decisiones profesionales, y algunos adolescentes poseen un rasgo de personalidad proactiva que aparentemente fortalece la relación entre los dos conceptos.

Método. Este estudio evaluó las relaciones entre la inteligencia emocional y la autoeficacia en la toma de decisiones profesionales y consideró si dichas relaciones son moderadas (fortalecidas o debilitadas) por la personalidad proactiva. Se encuestó una muestra grupal $(N=$ 840) de escuelas secundarias estatales superiores en Indonesia.

Resultados. La autoeficacia en la toma de decisiones profesionales se correlacionó con la inteligencia emocional. Además, la personalidad proactiva tuvo un efecto moderador en la relación entre la inteligencia emocional y la autoeficacia en la toma de decisiones profesionales.

Discusión y Conclusion: Existe una relación positiva significativa entre los dos factores, y se acepta la hipótesis. El papel de la personalidad proactiva sugiere que las intervenciones profesionales deberían enfatizar los aspectos de la personalidad proactiva para aumentar la autoeficacia de los adolescentes en la toma de decisiones profesionales.

Palabras clave: Toma de decisiones de carrera autoeficacia; adolescente; inteligencia emocional; personalidad proactiva. 


\section{Introduction}

As a transition stage between childhood and adulthood, adolescence is a career crystallization period that occurs generally from age 14 to 18 (Tinsley, Bowman, \& York, 1989; Super, 1994; Muris \& Ollendick, 2002; Bokhorst, Westenberg, Oosterlaan, \& Heyne, 2008; Fuller \& Marler, 2009). Additionally, development in adolescence typically becomes more complex, as it aligns with cognitive development (Cofer, 1965; Steinberg, 2005). New high school graduates face decisions between embarking on a career or continuing their education, and they often encounter doubts and difficulties when choosing a career (Gati, Krausz, \& Osipow, 1996; Albion, 2000; Hirschi, Niles, \& Akos, 2011; Taber, 2013). Even if they continue their studies, they are frequently hesitant when deciding which courses are relevant to their desired careers.

An individual's ability to choose a career is known as career decision-making selfefficacy (Taylor \& Betz, 1983). While some adolescents may have enough confidence in their abilities to choose careers, Taylor and Betz (1983b) found that career indecision often occurs because of low levels of confidence in their abilities. Specifically, career decisionmaking self-efficacy is the ability to determine career specifications based on the individual adolescent (Choi, Park, Yang, Lee, Lee, \& Lee, 2012; Hsieh \& Huang, 2014; Jiang, 2014, 2016). The basic concept of career decision-making self-efficacy-in this case, social cognitive career theory (Lent, Brown, \& Hackett, 1994, 2000)—is based on Bandura's (1977) social cognitive theory.

Social cognitive career theory discusses career self-efficacy and explains several factors affecting career development (as cited by Choi et al., 2012; Lent et al., 1994, 2000). According to Choi et al. (2012), social cognitive career theory plays a role in developing selfefficacy and targets, and several factors contribute to career efficacy, such as social support and career barriers, both affecting self-efficacy fluctuations in actualizing career interests, targets, and performance. Thus, social cognitive career theory is a concept that applies career self-efficacy to career planning and development (Choi et al., 2012).

Several studies have explained the relation between career decision-making selfefficacy and demographic variables (Jiang, 2014; Baglama \& Uzunboylu, 2017). Mau (2000) found that males have higher career decision-making self-efficacy than females. Moreover, 
Baglama and Uzunboylu (2017) also found that age was correlated with career decisionmaking self-efficacy.

Furthermore, obstacles and challenges to one's career decision-making process include limited information, self-determination of required skills (Ballout, 2009), a difficult and highly competitive selection process (Santoso \& Himam, 2014), and the assessment of one's ability to support a career (Taylor \& Betz, 1983). These affect adolescents in that they judge themselves as unable to work on a chosen subject, resulting in hesitation and difficulty when deciding on a career. The effects of and challenges and doubts in career decision-making lead to the emergence of negative feelings and emotions, low self-esteem, anxiety, and poor social skills (Creed, Patton, \& Prideaux, 2006), as well as depression. Adolescents with high levels of depression exhibit low career decision-making self-efficacy (Rottinghaus, Jenkins, \& Jantzer, 2009). In this context, as described by Barone, Maddux, and Snyder (1997), depression makes adolescents believe they would be unable to achieve established goals. Psychological conditions caused by difficulties and doubts in determining careers are indicators of a weak ability to regulate emotion (Wong \& Law, 2002). Thus, for adolescents, positive emotions are highly implicated in perceptions of career decision-making self-efficacy (Rottinghaus et al., 2009), of which emotional intelligence is a salient predictor.

Petrides and Furnham (2006) described emotional intelligence as a collection of selfperceptions of emotion in the lowest level of personality hierarchy and disposition: emotion perception, emotional management, empathy, and impulsiveness. Emotional intelligence includes well-being, self-control, emotionality, and sociability (Petrides \& Furnham, 2006; Petrides, Pita, \& Kokkinaki, 2007), the last two dimensions being directly related with adaptability and self-motivation (Petrides \& Furnham, 2006; Petrides et al., 2007).

A significant correlation between emotional intelligence and proactive personality shows the ability of adolescents with high emotional intelligence to easily adapt to different environments and to contribute to their current conditions so that they are motivated to determine and realize their chosen plans and programs (Carson, Carson, \& Birkenmeier, 2016; Schutte \& Loi, 2014). Emotional intelligence also enhances attitudes, concerns, altruistic behaviors, and innovative programs for the environment (Carmeli et al., 2003). Schutte and Loi's (2014) findings suggest that adolescents with high emotional intelligence are significantly more likely to be satisfied with their social support and gain strength from their envi- 
ronment; therefore, emotional intelligence becomes an indicator that helps them advance in their surroundings.

Proactive personality is a stable personality trait linked with personal initiative and proactive behavior (Bateman \& Crant, 1993). Adolescents with proactive personality traits tend to take the initiative to change their environment, identify opportunities, realize actions, and diligently perform these actions until they achieve meaningful change (Allen, Weeks, \& Moffitt, 2005; Bateman \& Crant, 1993; Crant, 1995, 2000; Crant \& Bateman, 2000; Tolentino et al., 2014). Active adolescents are inclined to realize their aspirations and complete programs related to how they enrich their environments (Bandura, 1977; Brown, Cober, Kane, Levy, \& Shalhoop, 2006), and thus, they take the initiative to donate, form a trust system, self-regulate, and function individually to make an impact on their environment (Bandura, 2001, in Brown et al., 2006).

In the process of career decision-making self-efficacy, proactive personality drives the emergence of proactive behavior and helps individuals make changes, realize solutions to problems, and work on their careers and interests (Allen et al., 2005). Highly proactive adolescents are more inclined to engage in proactive behavior in self-appraisal, career information attainment, goal setting, and future-oriented problem-solving and planning. Thus, the relation between emotional intelligence and career decision-making self-efficacy seems highly dependent on proactive personality. Such a relation becomes stronger when adolescents' proactive personality is high and weaker if proactive personality is low.

\section{Objectives and Hypotheses}

Based on the relational dynamics of career decision-making self-efficacy, emotional intelligence, and proactive personality, this study aimed to test the hypothesis of an effect of emotional intelligence on career decision-making self-efficacy. It also hypothesized that proactive personality moderates emotional intelligence and career decision-making self-efficacy (Figure 1). 


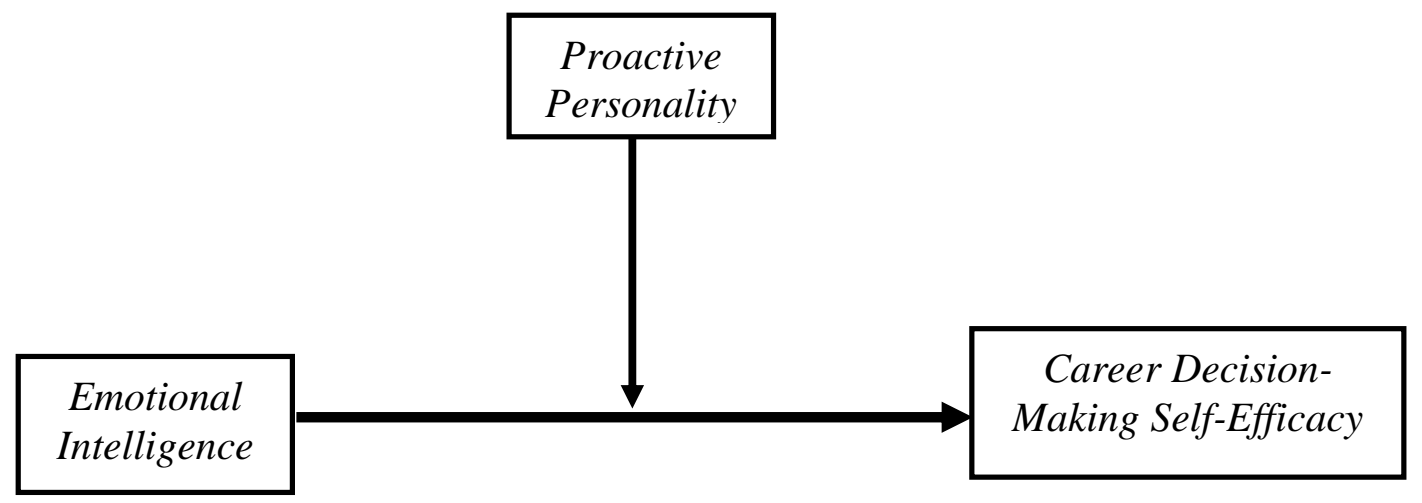

Figure 1. Schematic of dynamics among variables: the relation between emotional intelligence and career decision-making self-efficacy and the moderating effect of proactive personality.

\section{Method}

\section{Participants}

A survey was conducted with 840 adolescents at state senior high schools in Jakarta using instruments of career decision-making self-efficacy, emotional intelligence, and proactive personality. The study excluded students from vocational high schools. The respondents were $15(9.5 \%), 16(41.9 \%)$, and 17 years old (48.6\%), and the average and standard deviation for all ages were $(M=16.39 ; \mathrm{SD}=.66) ; 35.2 \%$ were males and $64.8 \%$ were females. Their parents' educational background ranged from elementary school to doctoral graduate (Table 1).

Table 1. Demographic Information

\begin{tabular}{lll}
\hline Demographic characteristics & $f$ & $\%$ \\
\hline Gender differences & & \\
Males & 296 & 35.2 \\
Females & 544 & 64.8 \\
Age & & \\
15 & 80 & 9.5 \\
16 & 352 & 41.9 \\
17 & 408 & 48.6 \\
\hline
\end{tabular}




\section{Instruments}

English-language instruments that measure career decision-making self-efficacy, emotional intelligence, and proactive personality were adapted into Bahasa.

Career Decision-Making Self-Efficacy Scale-Short Form. Career decision-making self-efficacy was measured using the Career Decision-Making Self-Efficacy Scale-Short Form, which Sawitri (2009) adapted into Indonesian. Taylor and Betz (1983) developed the instrument to measure adolescents' confidence in their ability to successfully complete career decision-related tasks, such as conducting accurate self-appraisal, gathering occupational information, selecting goals, making future plans, and problem-solving (Betz \& Hackett, 1986; Betz, Klein, \& Taylor, 1996; Taylor \& Betz, 1983; Taylor \& Popma, 1990).

Sawitri's (2009) adaptation of the instrument deleted 4 of the 25 items, so only 21 favorable statements were used in this study. Items were rated on a Likert-type scale from 1 (very unsure) to 6 (very sure). Model fit was $\chi^{2}=221.11$, df $=189, p=.05$, RMSEA $=.03$. For the scale's test reliability, internal consistency was $\alpha=.90$.

Trait Emotional Intelligence Questionnaire-Short Form (TEIQue-SF). This study also used the Trait Emotional Intelligence Questionnaire-Short Form (TEIQue-SF) developed by Petrides and Furnham (2006), which was later adapted into Indonesian version by Laensadi and Salim (2017) by adjusting it to the Indonesian culture. This research used Indonesian version's form adapted by Laensadi and Salim (2017). There were 30 items in TEIQue-SF. Then, validity and reliability test eliminated 13 items. Then, the modified form consisted of 17 items with responses rated on a Likert scale, from 1 (strongly disagree) to 6 (strongly agree).

There are six dimensions representing emotional intelligence. Petrides (2009) mentions six dimensions of TEIQue-SF, and that are trait positive/well-being, self-control, emotionality, sociability, adabtability, and self-motivtaion. The trait positive/well-being has three indicators - self-esteem, trait happiness, and optimism (Petrides et al., 2016; Petrides \& Furnham, 2006) — and was adapted by Salim (2018). Self-control consists of three indicators: emotion control, stress management, and impulse control (Petrides et al., 2016; Petrides \& Furnham, 2006). According to Petrides et al. (2016), the emotionality indicator includes emo- 
tional perception of oneself and others, emotional expression, relationships, and empathy. The sociability dimension consists of social awareness, emotional management of others, and assertiveness (Petrides et al., 2016; Petrides \& Furnham, 2006). The last two dimensions relate directly to adaptability and self-motivation (Petrides \& Furnham, 2006). Model fit was $\chi^{2}=264.58, \mathrm{df}=229, p=.05, \mathrm{RMSEA}=.02$. For the scale's test reliability, internal consistency was $\alpha=.85$.

Proactive Personality Scale (PPS). Bateman and Crant (1993) developed the unidimensional Proactive Personality Scale (PPS, Bateman \& Crant, 1993; Seibert, Crant, \& Kraimer, 1999). This study used the short version of the PPS developed by Seibert et al. (1999), which Preston and Salim (2017) adjusted to the Indonesian culture. For ten items of PPS, model fit for the PPS was $\chi^{2}=34.06, \mathrm{df}=26, p=.13$, RMSEA $=.04$. The internal consistency of the PPS was $\alpha=.76$ with three items eliminated. The adapted PPS consisted of seven items with favorable statements and used a Likert scale ranging from 1 (strongly disagree) to 6 (strongly agree).

\section{Procedure}

Before conducting the survey, the researcher obtained a study permit from the principal and educational authorities in the areas where each school was located. The researcher also obtained informed consent from participants and kept their identities confidential. Data were collected through convenience sampling; at the time, the participants who were recruited were those who were present, and they were not coerced into taking part in the study. The participants answered the questionnaires that were administered by the researcher. After completing the questionnaires, researcher gave them rewards (some accessories; such as ballpoints and book notes).

\section{Data Analysis}

The study used SPSS 23.0. For the moderation test of proactive personality on emotional intelligence and career decision-making self-efficacy, the study used PROCESS 3.0 developed by Hayes (2013). Testing the moderation hypothesis through PROCESS 3.0, we know that there exists a significant relation between emotional intelligence and career decision-making self-efficacy (Field, 2017). 


\section{Moderation Analysis}

We first tested the relation between emotional intelligence and career decision-making self-efficacy. Then, we tested the moderation role of proactive personality in such relation. Before the moderation analysis, we used a mean centering of emotional intelligence and proactive personality to establish the strength and weakness of the relation between emotional intelligence and career decision-making self-efficacy at low, mean/average, and high proactive personality (Field, 2017; Hayes, 2013). Next, moderation analysis was conducted by taking career decision-making self-efficacy as an outcome, emotional intelligence as a predictor, and proactive personality as moderator variable.

\section{Results}

Table 2 shows the calculated means, standard deviations, and correlations in emotional intelligence-career decision-making self-efficacy and proactive personality-career decision-making self-efficacy. The correlation between emotional intelligence and career decision-making self-efficacy explained that from an increase in career decision-making selfefficacy emerges an increase in emotional intelligence when the proactive personality value is $0(M=0$; Hayes, 2013). On the other hand, correlation between proactive personality and career decision-making self-efficacy indicated that variations in proactive personality affected career decision-making self-efficacy when emotional intelligence is 0 (Hayes, 2013).

Table 2 Means, Standard Deviations (SD), and Correlation Coefficients among Variables

\begin{tabular}{lcllllll}
\hline Variable & Mean & SD & 1 & 2 & 3 & 4 & 5 \\
\hline 1. Age & 16.39 & .655 & - & & & & \\
2. Gender & 1.65 & .478 & .002 & - & & & \\
3. EI & 3.721 & .508 & $.095^{* *}$ & $-.104^{* *}$ & - & & \\
4. PP & 4.400 & .575 & .064 & $-.076^{*}$ & $.303^{* *}$ & - & \\
5. CDMSE & 4.613 & .559 & $.099^{* *}$ & $-.027^{* *}$ & $.345^{* *}$ & $.525^{* *}$ & - \\
\hline
\end{tabular}

\footnotetext{
**Correlation is significant at $\mathrm{p}<.01$ (two-tailed).
}

Note: $\mathrm{EI}$ = emotional intelligence; $\mathrm{PP}$ = proactive personality; $\mathrm{CDMSE}$ = career decision-making self-efficacy; $1=$ Female; $2=$ Male. 
Besides means and standard deviations, Table 2 also presents coefficient relationships among emotional intelligence, proactive personality, and career decision-making selfefficacy. The results indicated positive and significant relationships between emotional intelligence and career decision-making self-efficacy $(r=.345, p<.01)$, between emotional intelligence and proactive personality $(r=.303, p<.01)$, and between proactive personality and career decision-making self-efficacy $(r=.525, p<.01)$ (Table 2$)$.

\section{Hypotheses Testing}

The research hypothesis points to an effect of emotional intelligence on career decision-making self-efficacy and a moderatoring role of proactive personality. Table 3 summarizes the results of the moderating tests on proactive personality toward the contribution emotional intelligence on career decision-making self-efficacy, showing the regression of interaction between emotional intelligence and proactive personality with career decision-making self-efficacy. Since a positive and significant relation exists between emotional intelligence and a significant moderating role of proactive personality on these emotional intelligence and career decision-making self-efficacy is tested, the initial hypothesis is supported.

Table 3. Summary of PROCESS: Scores of Dynamics among Variables

\begin{tabular}{ccccc}
\hline Variable & $b$ & SEB & $t$ & $p$ \\
\hline Constant & 4.622 & .016 & 279.321 & $.000^{* *}$ \\
& {$[4.590,4.655]$} & & & \\
EI & .232 & .033 & 6.994 & $.000^{* *}$ \\
& {$[.167, .297]$} & & & $.000^{* *}$ \\
PP & .450 & .029 & 15.447 & $.029 *$ \\
EI $\times$ PP & {$[.393, .507]$} & & & \\
& -.109 & .049 & -2.186 & \\
\hline
\end{tabular}

* Correlation is significant at $p<.05$.

**Correlation is significant at $p<.01$ (two-tailed).

$\mathrm{EI}=$ emotional intelligence $; \mathrm{PP}=$ proactive personality $; \mathrm{CDMSE}=$ career decision-making self-efficacy. 
As Table 3 shows, emotional intelligence and proactive personality are predictive factors of career decision-making self-efficacy. The impact of emotional intelligence on career decision-making self-efficacy $(b=.232,95 \%$ CI $[.167, .297], t=6.994, p<.01)$ appears positive and significant. Meanwhile, the interaction between the two predictors (emotional intelligence $\times$ proactive personality) was found to significantly affect career decision-making selfefficacy $(b=-.109,95 \%$ CI $[-.206,-.011], t=-2.186, p<.05)$, on which adds $.3 \%$ on explaining variance $\left(\Delta R^{2}=.003\right)$.

Table 4. Summary of the Moderating Effects of Proactive Personality

\begin{tabular}{cccccccc}
\hline Condition of PP & $B$ & $S E B$ & $t$ & $p$ & $R$ & $R^{2}$ & $\Delta R^{2}$ \\
\hline Low & .294 & .046 & 6.448 & $.00^{* *}$ & .564 & .318 & .003 \\
{$[-.576]$} & {$[.205, .383]$} & & & & & & \\
Average & .232 & .033 & 6.994 & $.00^{* *}$ & & & \\
{$[.00]$} & {$[.167, .297]$} & & & & & & \\
High & .170 & .042 & 4.050 & $.00^{* *}$ & & & \\
{$[.576]$} & {$[.087, .251]$} & & & & & & \\
\hline
\end{tabular}

${ }^{* *}$ Correlation is significant at $p<.01$.

Table 4 and Figure 2 illustrate the effect of some conditions of proactive personality on the influence of emotional intelligence on career decision-making self-efficacy. It indicates three proactive personality conditions that affect the quality of the relation between emotional intelligence and career decision-making self-efficacy: (1) low, at -.576 ( $B=.294$, 95\% CI [.204, .384], $t=6.448, p<.01$ ); (2) average, in the centered score of the proactive personality variable with a mean score of $0(B=.232,95 \%$ CI $[.167, .297], t=6.994, p<$ $.01)$; and (3) high, with the score above mean centering, at $.576(B=.169,95 \%$ CI [.087, $.251], t=4.051, p<.01)$.

As explained previously, Table 4 indicate the role of proactive personality when moderates emotional intelligence and career decision-making self-efficacy at low, average, and high. When proactive personality was high, a positive and significant relation emerged between emotional intelligence and career decision-making self-efficacy. When proactive personality was average, or at the average, a positive and significant relation existed between 
emotional intelligence and career decision-making self-efficacy, with a lower level of relation than in the high condition. In the low proactive personality condition, there was a positive and significant relation between emotional intelligence and career decision-making selfefficacy, with a lower level of relation than in the high and average conditions. These results support the second hypothesis that proactive personality (at low, average, and high values) significantly moderates the regression on emotional intelligence with career decision-making self-efficacy.

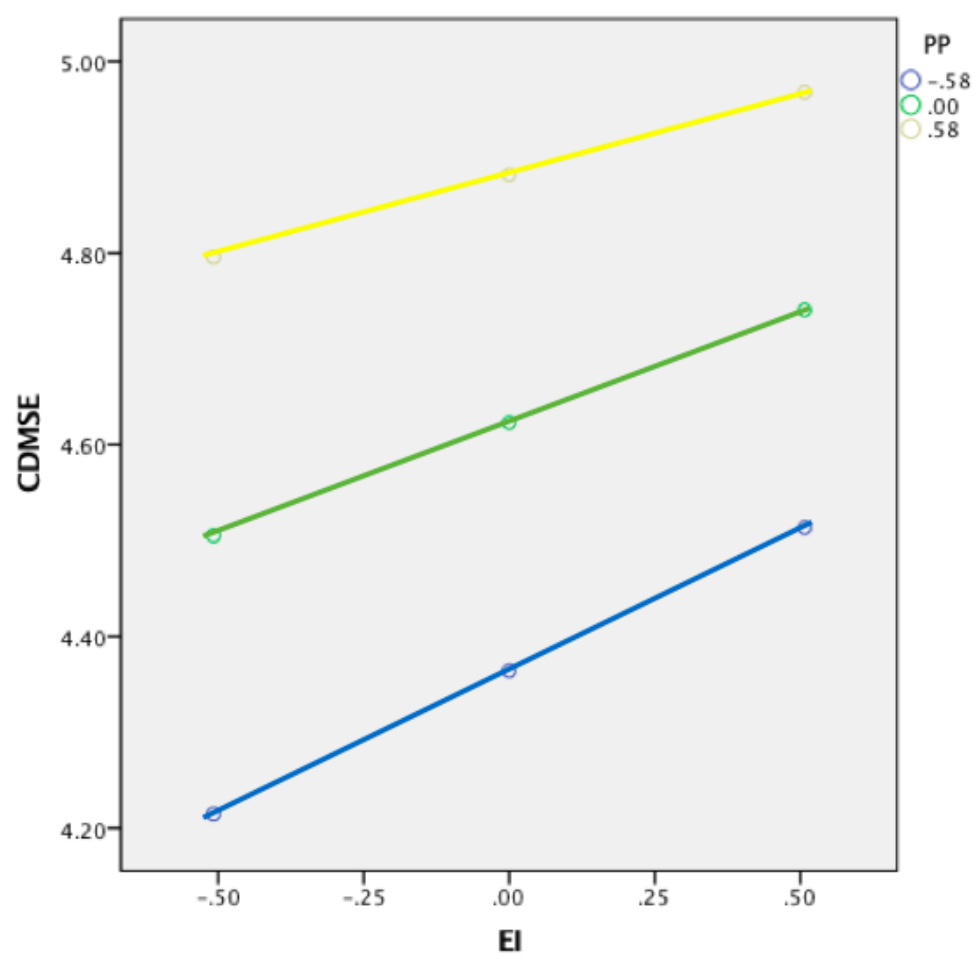

Figure 2. Interaction graph representing the moderation effect. It includes the moderating condition of proactive personality at low, average, and high levels.

Note: $\mathrm{EI}=$ emotional intelligence $; \mathrm{PP}=$ proactive personality $; \mathrm{CDMSE}=$ career decision-making self-efficacy.

\section{Discussion and conclusion}

This study aimed to examine the relations among emotional intelligence, proactive personality, and career decision-making self-efficacy. The study results were consistent with previous findings (Barone et al., 1997; Rottinghaus et al., 2009) of a positive and significant relation between emotional intelligence and career decision-making self-efficacy. Emotional intelligence was also found to be a salient predictor that increases adolescents' confidence in 
making decisions with regard to their careers. Thus, the research results supported the first hypothesis.

The results of research on the contribution of emotional intelligence to career decision-making self-efficacy are in accordance with the results of research conducted by Puffer (2011), Hess and Bacigalupo (2011), and Di Fabio and Kenny (2011). This indicates that emotional intelligence also takes a role in several mental processes (Caroll, 1993; Mayer \& Salovey, 1997). Overall, this study's results show that when senior high school adolescents' emotional intelligence is higher, it causes career decision-making self-efficacy increasing accordingly. Conversely, lower emotional intelligence leads to lower career decision-making self-efficacy. Unstable emotional states, such as career-related anxiety, make adolescents less convinced of their ability to decide on their careers.

The rationale behind this study's findings is that emotionally stable adolescents are in a good position to actualize their mind-set and believe in their career decision-making ability. Emotional intelligence, structured on intelligence and emotion, is a component of cognitive ability (Jafri, Dem, \& Choden, 2016). Adolescents with high emotional intelligence are more creative and elaborative, lean toward divergent thinking, and possess other cognitive-process skills related to ideas or thoughts (Jafri et al., 2016).

Mayer, Caruso, and Salovey (2016) stated that emotional intelligence plays a role in processing cognition-related ideas and thoughts. Emotions involved in facilitating thoughts are reflected in a number of ways, including analyzing problems at hand and leading individuals to relevant solutions or predictions (Mayer et al., 2016). Furthermore, Mayer et al. (2016) described the emergent cognition dimension in the presence of individual emotional stability and individual mood changes with implications for cognitive perspectives. In addition, emotion has implications for judging and remembering (Mayer et al., 2016).

Mayer et al.’s (2016) work on emotional intelligence and cognition demonstrates how adolescents can use their emotional intelligence to facilitate career decision-making selfefficacy. Emotion that is in control, stable, and in good condition affects the individual's selfappraisal, career-focused information gathering, goal prioritization for their desired career, career planning, problem-solving regarding career Search, and decision-making. Thus, emotional intelligence is a critical component of career decision-making self-efficacy. 
This study's findings explain how proactive personality contributes to emotional intelligence and career decision-making self-efficacy and are consistent with research by Hsieh and Huang (2014). Senior high school adolescents with highly proactive personalities are more confident in their career choices. Senior high school adolescents require a proactive personality before they are able to determine proactive behavior (Fuller \& Marler, 2009; Tolentino et al., 2014). They can take initiative and explore new experiences by using their emotions to guide their mind-set and actions regarding accurate self-appraisal, occupational information gathering, goal selection, future planning, and problem-solving (Taylor \& Betz, 1983, 1983b; Taylor \& Popma, 1990; Betz et al., 1986).

In this case, proactive personality moderates the relation between emotional intelligence and career decision-making self-efficacy in that both variables depend on it. The higher the emotional intelligence, the higher the career decision-making self-efficacy; this is caused by the moderating effect of proactive personality despite its tendency to weaken the relation between the two variables. When proactive personality is low, the relation between emotional intelligence and career decision-making self-efficacy is strong. Conversely, when proactive personality is high, the relation between emotional intelligence and career decision-making self-efficacy is weak. Simply put, proactive personality improves and undermines the link between emotional intelligence and career decision-making self-efficacy.

Furthermore, the results of the study that the effect of emotional intelligence on career decision-making self-efficacy is strengthened when proactive personality in low conditions indicates that the condition of students with lower proactive personality tends to adapt to the environment rather than changing it (Crant, 2000). While students with high proactive personality tend to initiative for making a positive contribution to change the environment, students with low proactive personality appear to be more reactive to initiatives changing environment (Crant, 2000). Thus, in a stable emotional state, students are increasingly convinced of their ability to decide on a career as desired depending on their tendencies when adapting to the variety of career choices according to most societies' choices.

Our study suggests that the influence of emotional intelligence on career decisionmaking self-efficacy requires the presence of proactive personality. The results also show that the higher the moderating effect of proactive personality, the closer to zero the regression of 
emotional intelligence on career decision-making self-efficacy, but such relation is generally positive. An increase of one unit in proactive personality can significantly influence career decision-making self-efficacy due to changes in emotional intelligence.

The study results on emotional intelligence, proactive personality, and career decision-making self-efficacy provided several limitations and points to consider for further research, as follows:

1. The researchers included only internal factors. Studies of external factors related to developmental tasks in career determination are necessary; these factors may include parenting style, parenting support, peer support, social support, and parental and social demands. Hsieh and Huang (2014) examined the relations among socioeconomic status, proactive personality, and career decision-making self-efficacy and found that senior high school adolescents with low socioeconomic status conducted more career planning to improve their socioeconomic status.

2. This research used a survey, which means it would be beneficial for future studies to conduct experimental research related to assessments that are based on career-selection modules. In fact, before conducting the study, the current researcher prepared a careerplanning intervention module and administered surveys on career decision-making selfefficacy, emotional intelligence, and proactive personality to determine any pre-intervention and post-intervention differences.

3. This study focused on state senior high school students. Thus, it would be necessary to compare them with state vocational high school students, as although both types of high schools teach science, state senior high schools have a more theoretical approach to knowledge, natural sciences, social sciences, and language. Meanwhile, state vocational high schools focus more on providing skills and theoretical aspects related to students' intended vocations. To prevent state senior high students from focusing solely on theoretical aspects, educational institutions need to equip them with skills related to career determination. Skills and career debriefing should be provided through information that is specific to students' target fields of study as well as their locale, in this case, Indonesia. Such provisions will hopefully improve their career confidence. 
4. This research used moderator test analysis to reveal the moderating role of proactive personality. Future research could use multiple regression data analysis, which regresses the outcome predictors; factorial design data analysis; and two-way ANOVA by converting predictor variables (continuous variables) into dummy variables (Field, 2017). Also, by including the relevant theory and literature review, variable dynamics can use proactive personality to influence emotional intelligence and career decision-making self-efficacy.

5. This study was conducted only in Jakarta, which is an urban area. Further research must compare cultural factors in areas around Jakarta, Sumatera, Kalimantan, and some areas in eastern Indonesia, for instance.

6. Based on the research results, this study contributes to career decision-making selfefficacy especially as predicted by emotional intelligence and moderated by proactive personality. This provides insight for teachers, school psychologists, parents, peers, and educators working in school guidance and counseling to provide intervention programs that emphasize emotional intelligence and proactive personality aspects in career decision-making selfefficacy.

Overall, this study's results confirmed our expectations about the significant moderating role of proactive personality between emotional intelligence and career decision-making self-efficacy. The higher the subjects' proactive personality, the higher the relation between their emotional intelligence and career decision-making self-efficacy. Therefore, schools and parents need to promote emotional intelligence and proactive personality in career decisionmaking self-efficacy among high school adolescents.

\section{References}

Albion, M. (2000). Career Decision Making Difficulties of Adolescent Boys and Girls, 9, 14-19. Retrieved from http://eprints.usq.edu.au/id/eprint/2918.

Allen, D. G., Weeks, K. P., \& Moffitt, K. R. (2005). Turnover intentions and voluntary turnover: the moderating roles of self-monitoring, locus of control, proactive personality, and risk aversion. Journal of Applied Psychology, 90, 980. https://doi.org/10.1037/0021-9010.90.5.980.

Baglama, B., \& Uzunboylu, H. (2017). The relationship between career decision-making self-efficacy and vocational outcome expectations of preservice special education teachers. South African Jour- 
nal of Education, 37. http://dx.doi.org/10.15700/saje.v37n4a1520.

Ballout, H. I. (2009). Career commitment and career success: moderating role of, Career Development International, 14, 655-670. https://doi.org/10.1108/13620430911005708

Bandura, A. (1977). Social learning theory, New Jersey, NJ: Prentice-Hall, Englewood Cliffs.

Barone, D. F., Maddux, J. E., \& Snyder, C. R. (1997). Self-regulation: The pursuit of goals. In Social Cognitive Psychology (pp. 277-303). Springer, Boston, MA.

Bateman, T. S., \& Crant, J. M. (1993). The proactive component of organizational behavior: A measure and correlates. Journal of Organizational Behavior, 14, 103-118. https://doi.org/10.1002/job.4030140202.

Betz, N. E., \& Hackett, G. (1986). Applications of self-efficacy theory to understanding career choice behavior. Journal of Social and Clinical Psychology, 4, 289. https://doi.org/10.1521/jscp.1986.4.3.279.

Betz, N. E., Klein, K. L., \& Taylor, K. M. (1996). Evaluation of a short form of the career decisionmaking self-efficacy scale. Journal of Career Assessment, 4(1), 47-57. doi:10.1177/106907279600400103.

Bokhorst, C. L., Westenberg, P. M., Oosterlaan, J., \& Heyne, D. A. (2008). Changes in social fears across childhood and adolescence: Age-related differences in the factor structure of the Fear Survey Schedule for Children-Revised. Journal of Anxiety Disorders, 22, 135-142. https://doi.org/10.1016/j.janxdis.2007.01.014.

Bokhorst, C. L., Westenberg, P. M., Oosterlaan, J., \& Heyne, D. A. (2008). Changes in social fears across childhood and adolescence: Age-related differences in the factor structure of the Fear Survey Schedule for Children-Revised. Journal of Anxiety Disorders, 22, 135-142. https://doi.org/10.1016/j.janxdis.2007.01.014.

Brown, D. J., Cober, R. T., Kane, K., Levy, P. E., \& Shalhoop, J. (2006). Proactive personality and the successful job search: A field investigation with college graduates. Journal of Applied Psychology, 91, 717. https://doi.org/10.1037/0021-9010.91.3.717.

Brown, D. J., Cober, R. T., Kane, K., Levy, P. E., \& Shalhoop, J. (2006). Proactive personality and the successful job search: A field investigation with college graduates. Journal of Applied Psychology, 91, 717. https://doi.org/10.1037/0021-9010.91.3.717.

Carmeli, A., Prati, L. M., Douglas, C., Ferris, G. R., Ammeter, A. P., \& Buckley, M. R. (2003). The relationship between emotional intelligence and work attitudes, behavior and outcomes: An examination among senior managers. Journal of Managerial Psychology, 18, 788-813. https://doi.org/10.1108/02683940310511881.

Carroll, J. B. (1993). Human cognitive abilities: A survey of factor-analytic studies. New York, NY: Cambridge University Press.

Carson, K. D., Carson, P. P., \& Birkenmeier, B. J. (2016). Measuring emotional intelligence: Development and validation of an instrument. Journal of Behavioral and Applied Management, 2, 33- 
47.

Choi, B. Y., Park, H., Yang, E., Lee, S. K., Lee, Y., \& Lee, S. M. (2012). Understanding career decision self-efficacy: A meta-analytic approach. Journal of Career Development, 39, 443-460. https://doi.org/10.1177/0894845311398042.

Cofer, C. N. (1965). Psychological review. A theory of cognitive development: The control and construction of hierarchies of skills. American Psychologist, 20, 713-713. https://doi.org/10.1037/h0021465.

Crant, J. M. (1995). The Proactive Personality Scale and objective job performance among real estate agents. Journal of Applied Psychology, 80(4), 532-537.doi:10.1037/0021-9010.80.4.532.

Crant, J. M. (2000). Proactive behavior in organizations. Journal of Management, 26, 435-462. https://doi.org/10.1016/S0149-2063(00)00044-1.

Crant, J. M., \& Bateman, T. S. (2000). Charismatic leadership viewed from above: The impact of proactive personality. Journal of Organizational Behavior,21, 63-75. Retrieved from http://www.jstor.org/stable/3100405.

Creed, P., Patton, W., \& Prideaux, L. A. (2006). Causal relationship between career indecision and career decision-making self-efficacy: A longitudinal cross-lagged analysis. Journal of Career Development, 33, 47-65. https://doi.org/10.1177/0894845306289535.

Di Fabio, A., \& Kenny, M. E. (2011). Promoting emotional intelligence and career decision making among Italian high school students. Journal of Career Assessment, 19(1), 21-34. https://doi.org/10.1177/1069072710382530.

Di Fabio, A., \& Saklofske, D. H. (2014). Comparing ability and self-report trait emotional intelligence, fluid intelligence, and personality traits in career decision. Personality and Individual Differences, 64, 174-178. https://doi.org/10.1016/j.paid.2014.02.024.

Field, A. (2017). Discovering Statistics Using SPSS (5 ${ }^{\text {th }}$ ed.). London: SAGE Publication, Inc.

Fuller, B., \& Marler, L. (2009). Change driven by nature: A meta-analytic review of the proactive personality literature. Journal of Vocational Behavior, 75, 329-345. https://doi.org/10.1016/j.jvb.2009.05.008.

Gati, I., Krausz, M., \& Osipow, S. H. (1996). A taxonomy of difficulties in career decision making. Journal of Counseling Psychology, 43, 510-526. https://doi.org/10.1037/0022-0167.43.4.510.

Hayes, A., F. (2013). Introduction to mediation, moderation, and conditional process analyses; A regression-based approach. New York, NY: The Guilford Press.

Hess, J. D., \& Bacigalupo, A. C. (2011). Enhancing decisions and decision-making processes through the application of emotional intelligence skills. Management Decision, 49(5), 710721. https://doi.org/10.1108/00251741111130805.

Hirschi, A., Niles, S. G., \& Akos, P. (2011). Engagement in adolescent career preparation: Social support, personality and the development of choice decidedness and congruence. Journal of Adolescence, 34, 173-182. hittps://oi.org/10.1016j.adolescence.2009.12.009. 
Hsieh, H. H., \& Huang, J. T. (2014). The effects of socioeconomic status and proactive personality on career decision self-efficacy. Career Development Quarterly, 62, 29-43. https://doi.org/10.1002/j.2161-0045.2014.00068.x.

Jafri, M., Dem, C., Choden, S. (2016). Emotional intelligence and employee creativity: moderating role of proactive personality and organizational climate. Business Perspectives and Research, 4, 54-66. https://doi.org/10.1177/2278533715605435.

Jiang, Z. (2014). Emotional intelligence and career decision-making self-efficacy: National and gender differences. Journal of Employment Counseling, 51, 112-124. https://doi.org/10.1002/j.2161-1920.2014.00046.x.

Jiang, Z. (2016). Emotional intelligence and career decision-making self-efficacy: Mediating roles of goal commitment and professional commitment. Journal of Employment Counseling, 53, 30-47. https://doi.org/10.1002/joec.12026.

Laensadi, A. M., \& Salim, R. M. A. (2017, August). Parenting styles and career decision self-efficacy: The mediating role of thinking styles on gifted adolescents. The asia-pacific research in social science and humanities. Presented at The $2^{\text {nd }}$ Asia-pacific research in social science and humanities-Universitas Indonesia conference, Jakarta, Indonesia.

Lent, R. W., Brown, S. D., \& Hackett, G. (1994). Toward a unifying social cognitive theory of career and academic interest, choice, and performance [Monograph]. Journal of Vocational Behavior, 45, 79-122. https://doi.org/https://doi.org/10.1006/jvbe.1994.1027.

Lent, R. W., Brown, S. D., \& Hackett, G. (2000). Contextual supports and barriers to career choice: A social cognitive analysis. Journal of Counseling Psychology, 47, 36-49. https://doi.org/10.1037//0022-0167.47.1.36.

Mau, W.-C. (2000). Cultural differences in career decision-making styles and self-efficacy. Journal of Vocational Behavior, 57, 365-378. https://doi.org/10.1006/jvbe.1999.1745.

Mayer, J. D., \& Salovey, P. (1997). What is emotional intelligence? In P. Salovey, \& D. J. Sluyter (Hrsg.) (Eds), Emotional development and emotional intelligence (pp. 3-31). New York: Basic Books.

Mayer, J. D., Caruso, D. R., \& Salovey, P. (2016). The ability model of emotional intelligence: Principles and updates. Emotion Review, 8, 290-300. https://doi.org/10.1177/1754073916639667.

Mayer, J. D., Salovey, P., \& Caruso, D. R. (2008). Emotional intelligence: New ability or eclectic traits? American Psychologist, 63, 503-517. https://doi.org/10.1037/0003-066X.63.6.503.

Muris, P., \& Ollendick, T. H. (2002). The assessment of contemporary fears in adolescents using a modified version of the Fear Survey Schedule for Children-Revised. Journal of Anxiety Disorders, 16, 567-584. https://doi.org/10.1016/S0887-6185(02)00106-8. 
Petrides, K. V. (2009). Psychometric properties of the trait emotional intelligence questionnaire (TEIQue). In Assessing emotional intelligence (pp. 85-101). https://doi.org/10.1007/978-0387-88370-0_5.

Petrides, K. V., \& Furnham, A. (2006). The role of trait emotional intelligence in a gender-specific model of organizational variables. Journal of Applied Social Psychology, 36, 552-569. https://doi.org/10.1111/j.0021-9029.2006.00019.x.

Petrides, K. V., Mikolajczak, M., Mavroveli, S., Sanchez-Ruiz, M. J., Furnham, A., \& PérezGonzález, J. C. (2016). Developments in trait emotional intelligence research. Emotion Review, 8, 335-341. https://doi.org/10.1177/1754073916650493.

Petrides, K. V., Pita, R., \& Kokkinaki, F. (2007). The location of trait emotional intelligence in personality factor space. British Journal of Psychology, 98, 273-289. https://doi.org/10.1348/000712606X120618.

Preston, M., \& Salim, R. M. A. (2017, August). Attribution for career decision making, proactive personality, and career decision self-efficacy in gifted high school students. The asia-pacific research in social science and humanities. Presented at The $2^{\text {nd }}$ Asia-pacific research in social science and humanities-Universitas Indonesia conference, Jakarta, Indonesia.

Puffer, K. A. (2011). Emotional intelligence as a salient predictor for collegians' career decision making. Journal of Career Assessment, 19(2), 130-150.https//doi.org/10.1177/1069072710385545.

Rottinghaus, P. J., Jenkins, N., \& Jantzer, A. M. (2009). Relation of depression and and self-efficacy in college students. Journal of Career Assessment, 17, 271-285. https://doi.org/10.1177/1069072708330463.

Santoso, E. I., \& Himam, F. (2014). Pengaruh Berbagi Pengetahuan Perencanaan Karir Terhadap Efikask Diri dalam Membuat Keputusan Karir. Jurnal Intervensi Psikologi, 6, 1-24. https://doi.org/10.20885/intervensipsikologi.vol6.iss1.art1.

Sawitri, D. R. (2009). Pengaruh status identitas dan efikasi diri keputusan karir terhadap keraguan mengambil keputusan karir pada mahasiswa tahun pertama di universitas diponegoro. Junal Psikologi Undip. Retrieved form http://www.psikologi.undip.ac.id.

Schutte, N. S., \& Loi, N. M. (2014). Connections between emotional intelligence and workplace $\begin{array}{llll}\text { flourishing. Personality } \quad \text { and Individual } \quad \text { Differences, 66, } & \text { 134-139. }\end{array}$ https://doi.org/10.1016/j.paid.2014.03.031.

Seibert, S. E., Crant, J. M., \& Kraimer, M. L. (1999). Proactive personality and career success. Journal of ap$\begin{array}{llllll}\text { plied } & \text { psychology, } & 84, & 416 . & \text { Retrieved }\end{array}$ https:/www.researchgate.net/profile/Maria_Kraimer/publication/12919548_Proactive_Personality_and_Career_Su ccess/links/09e4150d4alcbd06e8000000/Proactive-Personality-and-Career-Success.pdf.

Steinberg, L. (2005). Cognitive and affective development in adolescence. Trends in Cognitive Sciences, 9, 69-74. https://doi.org/10.1016/j.tics.2004.12.005.

Super, D. E. (1994). A life span, life space perspective on convergence. In M. L. Savikas \& R. W. 
Lent (Eds.), Convergence in career development theories: Implications for science and practice (pp. 63-74). Palo Alto, CA, US: CPP Books.

Taber, B. J. (2013). Time Perspective and Career Decision-Making Difficulties in Adults. Journal of Career Assessment, 21, 200-209. https://doi.org/10.1177/1069072712466722.

Taylor, K. M., \& Betz, N. E. (1983a). Applications of self-efficacy theory to the understanding and treatment of career indecision. Journal of Vocational Behavior, 22, 63-81. https://doi.org/10.1016/0001-8791(83)90006-4.

Taylor, K., M., \& Betz, N. E. (1983b). Applications of self-efficacy theory to the understanding and treatment of career indecision, Journal of Vocational Behavior,22, 63-81. https://doi.org/10.1016/0001-8791(83)90006-4.

Taylor, M., \& Popma, J. (1990). An examination of the relationships among career decision- making self-efficacy, career salience, locus of control, and vocational indecision. Journal of Vocational Behavior 37, 31, 17-31. https://doi.org/10.1016/0001-8791(90)90004-L.

Tinsley, H. E., Bowman, S. L., \& York, D. C. (1989). Career Decision Scale, My Vocational Situation, Vocational Rating Scale, and Decisional Rating Scale: Do they measure the same constructs? Journal of Counseling Psychology, 36(1), 115-120. https://doi.org/10.1037/00220167.36.1.115.

Tolentino, L. R., Garcia, P. R. J. M., Lu, V. N., Restubog, S. L. D., Bordia, P., \& Plewa, C. (2014). Career adaptation: The relation of adaptability to goal orientation, proactive personality, and ca$\begin{array}{lllll}\text { reer optimism. Journal of } & \text { Bocational }\end{array}$ https://doi.org/10.1016/j.jvb.2013.11.004.

Wong, C. S., \& Law, K. S. (2002). The effects of leader and follower emotional intelligence on performance and attitude: An exploratory study. The Leadership Quarterly, 13, 243-274. https://doi.org/10.1016/S1048-9843(02)00099-1.

Received: $22-08-2019$

Accepted: $20-01-2020$ 